\title{
Effect of Interest Rate Regulation on the Relationship Between Loan Underwriting Procedures and Financial Performance of Commercial Banks in Kenya
}

\author{
Hellen Araka ${ }^{1} \mathrm{PhD}_{\text {Candidate }}$ Dr. Vitalis Mogwambo ${ }^{2} \quad$ Dr. Simeyo Otieno ${ }^{2}$ \\ 1.School of Business and Economics, Department of Finance and Acoounting, Jaramogi Oginga Odinga \\ University of Science and Technology (Teachers Service Commisiion P.o. Box 673-40300 Homabay), Kenya \\ 2.School of Business and Economics, Department of Finance and Accounting, Jaramogi Oginga Odinga \\ University of Science and Technology P.o. Box 210-40601 Bondo, Kenya
}

\begin{abstract}
The first objective was to determine the relationship between collateral requirements (credit history of customer, customer income) and financial performance of commercial banks in Kenya. The second objective was to determine the effect of interest rate regulation on the relationship between loan underwriting procedures and financial performance of commercial banks in Kenya. The study used descriptive and correlation research design and the research philosophy used was positivism. The study adopted a census survey and purposive sampling method targeting 43 bank managers, 43 credit managers and 43 operations managers of the 43 commercial banks in Kenya for period 2013 to 2018. Document analysis guide was used to collect secondary quantitative data for period 2013 to 2018 from the commercial bank's financial reports and questionnaires were used to collect primary data. Data was analyzed using multiple linear regression method. The findings of the study revealed that loan underwriting procedures; collateral requirements measured by (credit history of customer and customer income) have a significant and negative impact on ROA of commercial banks in Kenya. The study findings revealed that there exists a relationship between interest rate regulation, loan underwriting procedures and financial performance of commercial banks in Kenya. The study recommended that commercial banks should strengthen its loan underwriting procedures, use the services of Credit Reference Bureau, train credit officers on how to scrutinize customers and give out loans which have collateral security only.
\end{abstract}

Keywords: Loan underwriting, interest rate regulation, financial performance, commercial banks, collateral requirements.

DOI: $10.7176 / \mathrm{RJFA} / 12-4-04$

Publication date: February $28^{\text {th }} 2021$

\subsection{Introduction}

Loan underwriting in the banking sector performs a critical function of appraising the credit worthiness of a potential customer and whether or not to offer a loan. The loan underwriters appraise the credit history of the customer through their past financial record statements and value of collateral provided among other parameters. Underwriting is the process through which an individual or institution takes on financial risk for a fee. The risk most typically involves loans, insurance or investment. The term underwriter originated from the practice of having risk takers writing their names against the total amount of risk they are willing to accept for a specified premium. SMEs often rely on personal savings or even borrowing from relatives to meet their financial obligations, nevertheless, when an SME does not access finance, they usually turn to the commercial banks as their primary source of finance. Many SMEs are not successful in accessing funding from financial institutions because they lack lending requirements which include collateral security in case of loan default (Githinji 2019)

(Ngetich 2011) defines interest rate as money borrowers pay for the use of money they borrow from the lender or financial institutions as a fee on borrowed asset. (Lakley 2013) defined loan underwriting as the process that banks undertake to analyze all the information provided by each loan applicant and their credit file to assess whether or not that applicant meets the banks' minimum loan criteria. As part of the process all data is verified, analyzed and summarized to paint a picture of each applicant. Underwriters assess the borrower's ability to repay the loan based on an analysis of their credit capacity and collateral.

(Blakley 2013) stated that application for loan mortgage or personal loan in U.S.A passes from the hands of the loan processor to the desk of the underwriter. In the mortgage underwriting process, the underwriter will make sure that the borrower's financial profile matches with the lender's guidelines and loan criteria, then the underwriter will make the final decision whether to approve or deny the loan request. The work of the underwriter is to assess risk and he/she will consider the following factors: if the borrower has ever gone bankrupt, gone foreclosure and if the borrower pays his bills/loans in time. These factors will reveal on how to manage debt and predict the ability of the borrower for loan/mortgage repayment. The underwriter will follow the three Cs of underwriting: capacity; if the borrower has resources to pay the debt. Credit; the underwriter will assess if the borrower has a solid repayment and credit history. In most cases they contact the credit reference bureaus. 
Collateral; the underwriter will consider the value and the type of the borrower's property being financed or the ability of his salary to repay the loan, which if he/she does not pay, the loan balance will be recovered from his property.

\subsection{Research Objectives}

The objective of the study was to determine the effct of interest rate regulation on the relationship between loan underwriting procedures on the financial performance of commercial banks in Kenya. Two specific objectives were derived from the main objective of the study and are as follows:

(i) To establish the relationship between collateral requirements on financial performance of commercial banks in Kenya

(ii) To determine the effect of interest rate regulation on the relationship between loan underwriting procedures and financial performance of commercial banks in Kenya

\subsection{Research Hypotheses}

(i) $\quad \mathbf{H}_{01}$ : There is no significant relationship between interest rate regulation on the relationship between collateral requirements and financial performance of commercial banks in Kenya.

(ii) $\quad \mathbf{H}_{\text {02: }}$ Interest rate regulation has no significant effect on the relationship between loan underwriting procedures and financial performance of commercial banks in Kenya.

a. Interest rate regulation has no significant effect on the relationship between the collateral requirements and financial performance of commercial banks in Kenya.

\section{THEORIES AND MODELS OF LOAN UNDERWRITING PROCEDURES}

\subsection{Loan Underwriting Procedures}

Loan underwriting is the process through which an individual or institution takes on financial risk to give out credit /loan at a fee mostly known as interest. The underwriting in the banking sector performs a critical function of appraising the credit worthiness of a potential customer and whether or not to offer a loan. They appraise the credit history of the customer through their past financial records, financial statements and value of collateral provided among other parameters. It is important that the customer's loan request be backed up by the correct kind of collateral because if the correct collateral is not used, it will negatively affect the balance sheet of the bank (Espinoza 2018).

\subsection{Interest Rate Regulation}

(Nakayiza 2013) stated that interest rate is a rate which is charged or paid for the use of money. An interest rate is often expressed as an annual percentage of the principal. It is calculated by dividing the amount of interest by the principal amount. In general, interest rates rise in times of inflation, greater demand of credit, tight money supply or due to higher reserve requirements for banks. A rise in interest rate for any reason tends to lessen business activity because credit and stock market becomes more expensive as investors can get better returns from bank deposits or newly issued bonds or loans than from buying shares.

Table 2.1 Effect of Interest rate regulations in Kenya

\begin{tabular}{lccccc}
\hline & Year & Loans Lent & NPLs & Growth in Credit & Profits \\
\hline \multirow{3}{*}{ Commercial } & 2013 & 3.50 tribillion & $8.7 \%$ & $18.4 \%$ & $16-20 \%$ \\
Banks & 2014 & 3.20 tribillion & $5.6 \%$ & $17.7 \%$ & $15-20 \%$ \\
& 2015 & 3.50 tribillion & $6.8 \%$ & $17.4 \%$ & $15-20 \%$ \\
& 2016 & 2.45 tribillion & $8.5 \%$ & $16.8 \%$ & $15-20 \%$ \\
& 2017 & 2.28 tribillion & $9.1 \%$ & $4.3 \%$ & $10-12 \%$ \\
& 2018 & 2.32 tribillion & $9.3 \%$ & $5.2 \%$ & $13-14 \%$
\end{tabular}

Source: CBK, 2017

In table 2.1 above, it shows that profits in the commercial banks ware higher for period 2013 to 2015 but reduced in the period 2016 to 2018 after the interest rate capping implying that interest rate capping affected the financial performance of commercial banks in Kenya.

\subsection{Collateral Requirements}

Collateral is an asset that a lender accepts as security for a loan. If the borrower defaults on the loan payments, the lender can seize the collateral and resell it to recoup the losses. Loans that are secured by collateral are typically available at substantially lower interest rates than unsecured loans. The borrower has a compelling reason to repay the loan on time. If the borrower defaults, the lender can seize the property and sell it to recoup some or all of the losses. The nature of the collateral is often predetermined by the loan type. For a home buyer, the house is the collateral for the mortgage. For a car buyer, the car is the collateral for the loan. Another type of borrowing is the 
collateralized personal loan, in which the borrower offers an item of value as security for a loan. The interest rate offered will be more favorable than when the loan was not secured. The value of the collateral must meet or exceed the amount being loaned (Githinji 2019).

\subsubsection{Credit History of Customer}

A credit history is a record of a borrower's responsible repayment of debts. A credit report is a record of the borrower's history from a number of sources including banks, credit card companies, collection agencies and governments. A borrower's credit score is the result of a mathematical algorithm applied to a credit report and other sources of information to predict future delinquency. In many countries when a customer submits an application for credit from a bank credit card company or a store, their information is forwarded to a credit bureau. The credit bureau matches the name, address and other identified information retained by the bureau in its files. The gathered records are then used by lenders to determine an individual's credit worthiness (Araka 2018).

\subsubsection{Customer Income}

The basics of the Five Cs of credit; the five Cs of credit method of evaluating a borrower incorporates both qualitative and quantitative measures. Lenders may look at a borrower's credit reports, credit scores, income statements and other documents relevant to the borrower's financial situation. They also consider information about the loan itself. The five Cs are as follows: character/credit history; a borrower reputation or track record for repaying debts. This information appears on the borrower's credit reports. Credit reports contain detailed information about how much an applicant has borrowed in the past and whether they have repaid loans on time. These reports also contain information on collection accounts and bankruptcies, and they retain most information for seven to ten years. Information from these reports helps lenders evaluate the borrower's credit risk.

\subsection{Financial performance of commercial banks}

(Mureithi 2013) viewed financial performance as an approximation for financial success which is the rate at which an enterprise is satisfied with the profits and growth level achieved by the firm. Financial performance of an enterprise is measured by return on assets (ROA), return on investment (ROI) and return on equity (ROE). It gives an idea on how efficient management is using its assets to generate earnings.

\subsubsection{Return on Assets}

Return on Assets (ROA) is a financial ratio that shows the percentage of profit a company earns in relation to its overall resources. It is commonly defined as net income divided by total assets.

Net income is derived from the income statement of the company and it is the profit after tax. ROA is an indicator of how profitable a company is relative to its total assets. ROA gives an idea as to how efficient management is at using its assets to generate earnings. It is calculated by dividing a company's annual earnings by its total assets. ROA helps investors to measure how management is using its assets or resources to generate more income.

Return on Assets $=$ Net Income/Total Assets.

Table 2.2 Commercial Bank's Profitability in Kenya

Name of Bank Year

\begin{tabular}{|c|c|c|c|c|c|c|}
\hline & 2013 & 2014 & 2015 & 2016 & 2017 & 2018 \\
\hline Equity Bank & $12.0 \%$ & $12.2 \%$ & $12.5 \%$ & $10.5 \%$ & $9 \%$ & $10.0 \%$ \\
\hline Cooperative Bank & $11.0 \%$ & $11.5 \%$ & $11.6 \%$ & $11.0 \%$ & $10 \%$ & $10.5 \%$ \\
\hline Standard Chartered Bank & $6.0 \%$ & $7.0 \%$ & $6.5 \%$ & $5.0 \%$ & $4 \%$ & $5.0 \%$ \\
\hline Barclays Bank & $5.5 \%$ & $6.0 \%$ & $6.2 \%$ & $6.0 \%$ & $5 \%$ & $6.0 \%$ \\
\hline
\end{tabular}

Source: CBK, 2017

\subsubsection{The classical theory of Interest Rate}

This theory was developed by Irving Fisher in 1936. Fisher's contribution rests fundamentally on a distinction between two interest rates, the real rate and the market rate. The real rate of interest is interest rate measured in terms of goods. According to this theory, the rate of interest is determined by the supply of and demand for savings. In money economy, however, as physical capital is purchased with monetary funds, the rate of interest is taken to be the annual rate of return over money capital invested in physical capital assets (Rochan and Vernengo, 2011).

2.8.1 Effect of the relationship between collateral requirements and financial performance of commercial banks

Githinji (2019) carried out a study on the effect of collateral requirements on financial performance of Agribusiness small and micro Enterprises in Nyeri Central Sub County, Kenya. The target population of the study was 950 licensed Agribusiness small and micro enterprises in Nyeri Sub County. A sample size of 274 licensed SMEs in the Nyeri central sub county was established by the use of Krejcie and Morgan's criterion. A cronbach alpha coefficient of 0.7 was used to evaluate the reliability of the semi-structured questionnaire. A response rate of 86.55 was achieved. Inferential statistics was carried out to ascertain the relationship between collateral requirements and financial performance of Agribusiness SMEs in Nyeri central sub county. Regression assumption of 
independence, linearity and normality were done. Results indicated that collateral requirements had negative and statistically insignificant effect on financial performance of Agribusiness SMEs. The study concluded that the collateral requirement by commercial banks affects the SMEs financial performance. The study recommended that Agribusiness SMEs should invest in capital assets which will assist them as collateral in time of accessing credit from commercial banks in order to enhance and sustain their financial performance.

2.7.2 Effect of interest rate regulation on the relationship between loan underwriting procedures and financial performance of commercial banks in Kenya

(Paulino 2018) carried out a study on credit risk management on the financial performance of commercial banks in Juba City, South Sudan. The target population of the study was 80 bank employees in the credit department of commercial banks of Juba city, South Sudan. The study used structured questionnaires in data collection. Data was analyzed quantitatively using the SPSS and the computed data was analyzed using descriptive statistics including frequencies, means and percentages. Interpretation of the data was done within the framework reference of the research problem. Linear regression analysis was used to analyze the data and it expressed the analysis as well as determined the relationship between the independent and dependent variables. The study established that the respondents of the study agreed that risk identification was well coordinated in their Bank. The study concluded that most of the banks consider risk identification as the process of credit risk management which affected performance of commercial banks. The study recommended that all banks operating across East Africa should have in place clearly defined policies on risk identification.

Independent Variable

Loan Underwriting Procedures

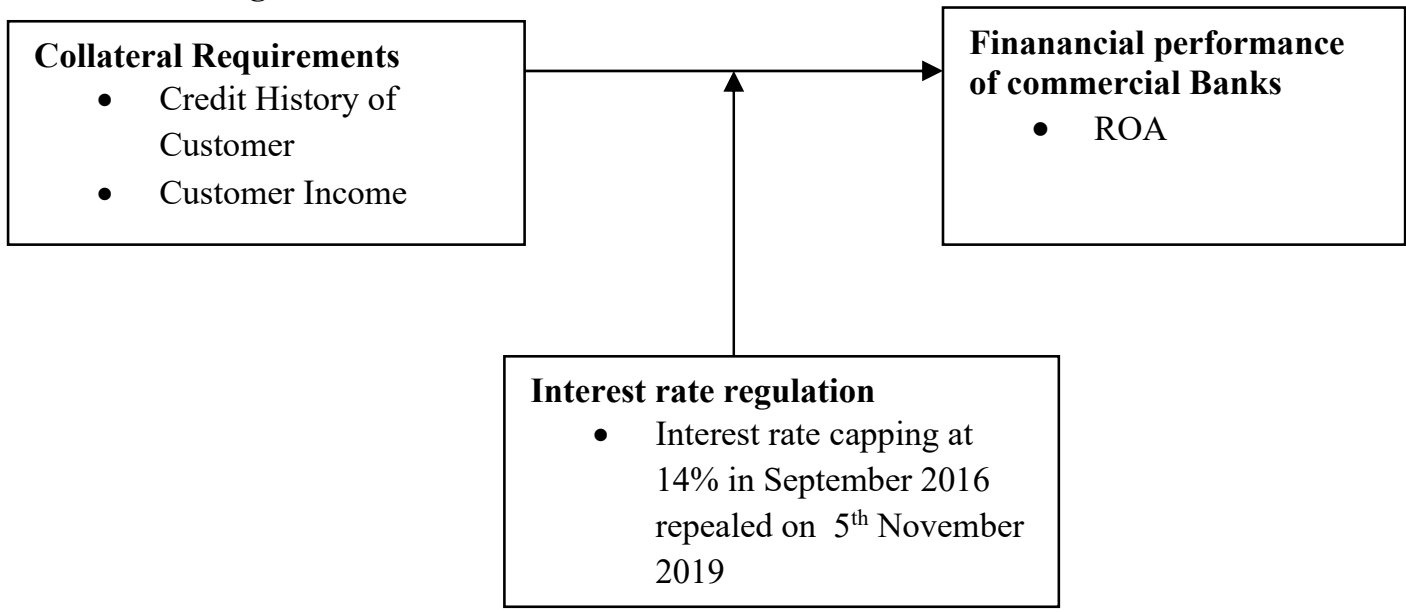

Fig 2.1 Conceptual Framework

Source: Researcher 2020

\subsection{Research Design}

The study adopted descriptive and correlation research design. The descriptive research design was appropriate because it involves the collection of numerical data to describe the situation or case under the research study. The descriptive research design is a theory based method which is created by gathering, analyzing and presenting the collected data. The study employed descriptive research design which aims to accurately and systematically describe a population, situation or a phenomen. It answers what, when where and how questions. It uses quantitative and qualitative methods to investigate one or more variables.

\subsection{Area of Study}

The research study area was all the 43 commercial banks registered in Kenya in Nairobi city which is the Headquarter of all the 43 commercial banks in Kenya.

\subsection{Target Population}

The target population of this study was 129 employees of all the 43 commercial banks registered in Kenya that is: 43 Bank managers, 43 operations managers and 43 credit managers. 
Table 3.1 Target Population

\begin{tabular}{lc}
\hline DESIGNATION OF BANK OFFICERS & NUMBER OF OFFICERS \\
\hline Bank Managers & 43 \\
Credit Managers & 43 \\
Operations Managers & 43 \\
Total & $\mathbf{1 2 9}$ \\
\hline
\end{tabular}

Source: Research, 2020

\subsection{Sampling Procedure and Sample Size}

The study adopted a Census survey Method and purposive sampling methods were used. The respondents of this study were 129 officers of all the 43 commercial banks registered in Kenya for the period of study (2013 - 2018). The respondents were 43 bank managers, 43 credit managers and 43 operations managers of all the 43 commercial banks registered in Kenya.

\subsection{Data Collection Procedure}

After receiving a letter of authorization for data collection from the Board of post graduate school, Document Analysis Guide was used to collect secondary quantitative data. The researcher collected primary data from the respondents of the employees of the commercial banks in Kenya who handle borrowers. The questionnaires were distributed to all the 43 commercial banks; to the credit, operations and bank managers by the researcher in the bank's Head offices in Nairobi. The filled questionnaires were collected after one week.

\subsection{Research Instruments}

The data collection instruments which were employed in this study were questionnaires which were used to collect primary data. Document Analysis Guide was used to collect secondary data. Document Analysis Guide was used to obtain commercial banks secondary data: 43 Bank managers, 43 operations managers and 43 credit managers. The study covered data for six years 2013 to 2018. The secondary data was collected from CBK offices or website on their annual reports on the commercial banks (Nduati 2013).

\subsection{Data Analysis}

Quantitative panel data analysis was adopted for conducting the econometric modeling. Panel data refers to the pooling of observations of separate units (countries, banks, groups of people) on the same set of variables over several time periods (Ogilo 2012). Panel data analysis for this study was executed by using both descriptive and inferential statistics techniques. The data collected was edited, coded and the analyzed using descriptive statistics. SPSS Version 22 software was used to generate descriptive statistics by way of mean, frequency tables and percentages. Inferential statistics was analyzed using multiple linear regression analysis model to test the statistical significance of the various independent variables loan underwriting procedures (collateral requirements) on the dependent variable of financial performance of commercial banks (Return on assets) together with moderating variable (Interest rate regulation) and the results was displayed on tables.

\subsubsection{Descriptive Analysis}

The mean and median which are the measures of Central tendency were used to indicate the middle and common occurring points in the data set for both explanatory and dependent variables. On the other hand, standard deviation is the measure of dispersion and was used to indicate the spread of the data around the mean. These measures were used to show the trend in commercial banks interest rate regulation, loan underwriting procedures and financial performance of commercial banks during the study period 2013 to 2015 before the capping of interest rates and 2016 to 2018 after the capping of interest rates.

\subsubsection{Correlation Analysis}

Correlation analysis was used to determine the direction of and strength of association between variables. This was done before conducting regression analysis or model estimation. Given that the study sought to establish the effect of interest rate regulation on the relationship between loan underwriting procedures and performance, Pearson ( $\mathrm{r}$ ) correlation coefficient was computed given the interval nature of the data and the need to test the direction and strength of association that exist among the study variables. Variance inflation factor (VIF) test was also performed for each explanatory variable entering the regression models to test for multi-collinearity.

\subsection{Diagnostic Tests for Regression Analysis}

The initial data analysis was done using the following methods: Normality, collinearity/unit root test, stationary test, heteroscedasticity and multicollinearity tests to evaluate whether the model used in the study is appropriate to address the research objectives and also to fulfill the assumption of classical linear regression model that is; its suitability, reliability and accuracy. 


\subsection{Empirical Models}

A model is a simplified view of reality designed to enable a researcher describe the essence and inter relationship within the system or phenomenon (Onmumere, 2015).

To measure the direct effect of the independent variables on the dependent variable the study utilized the model proposed by Athanasoglou et al (2006) and as used by Simeyo (2018). The models were modified and speficified as follows:

$$
Y_{i t}=\alpha_{i} Y_{i t-1}+\beta_{1} X_{1}+\beta_{2} X_{2}+u_{i t}
$$

$Y_{i t}$ : represent the dependent variable and measures ROA of bank $\mathrm{i}$ at time $\mathrm{t}$, with $i=1 \ldots \mathrm{n}$ and $t=1, \ldots \mathrm{T}$. $N=$ $\sum_{t=1}^{t} n_{i}$ represents the number of cross-sectional observations and $\mathrm{T}$ the length of the sample period.

$Y_{i t-1}$ is one year time lag ROA

$\mathrm{X}_{1}=$ Credit History of Customer $(\mathrm{CHC})$

$\mathrm{X}_{2}=$ Customer Income $(\mathrm{CI})$

$\beta_{1} \ldots \mathrm{B}_{6}=$ Regression coefficient

$u_{i t}, e_{i t}$ and $v_{i t}$ are error terms

To determine the effect of interest rate regulation on the relationship between loan underwriting procedures and financial performance of commercial banks in Kenya, the student t-test was first used to establish whether there was a statistically significant difference in the study variables before and after the interest rate capping and then Entity de-meaned OLS Fixed Effects estimation approach combined with changes specifications in which the difference in the mean ROA between the period before interest rate capping (2013-2015) and that after the interest rate capping (2016-2018) was regressed on the difference in independent variables between those two periods.

For model formulation, let $\mathbf{t}$ denote the period when interest rate capping came into effect such that (t-1) denotes the period before capping and $(\mathrm{t}+1)$ the period after capping.

First, the study applied the student t-test to establish whether there was a significant difference in means of $\mathrm{ROA}, \mathrm{CHC}$ and $\mathrm{CI}$ before and after the interest rate capping.

For ROA, the t-statistic was:

$$
T=\frac{\overline{y_{1}}-\overline{y_{2}}}{\sqrt{\frac{\sigma_{1}^{2}}{n_{1}}+\frac{\sigma_{2}^{2}}{n_{2}}}}
$$

Where $\overline{y_{1}}$ is the mean ROA before capping and $\overline{y_{2}}$ is the mean ROA after capping of interest rate. $\sigma_{1}^{2}$ is the variance of ROA before capping and $\sigma_{2}^{2}$ is the variance of ROA after capping. $n_{1}$ is total number of observation for the period before capping while $n_{2}$ is the total number of observations after capping. At $5 \%$ level of significance, the difference in the means will be statistically significant if the difference $\left(\overline{y_{1}}-\overline{y_{2}}\right)$ is more than $1.96 \times \sqrt{\frac{\sigma_{1}^{2}}{n_{1}}+\frac{\sigma_{2}^{2}}{n_{2}}}$. For the independent variables say $X_{j}$, the t-test statistic was:

$$
T=\frac{\bar{X}_{j 1}-\bar{X}_{j 2}}{\sqrt{\frac{\sigma_{j 1}^{2}}{n_{1}}+\frac{\sigma_{j 2}^{2}}{n_{2}}}}
$$

At 5\% level of significance, the difference in the means will be statistically significant if the difference $\left(\bar{X}_{j 1}-\bar{X}_{j 2}\right)$ is more than $1.96 \times \sqrt{\frac{\sigma_{j 1}^{2}}{n_{1}}+\frac{\sigma_{j 2}^{2}}{n_{2}}}$.

To establish whether Interest rate regulation had an effect on the relationship between collateral requirements and financial performance of commercial banks in Kenya, the following model was used:

Where

$$
\left(\bar{Y}_{i, t+1}-\bar{Y}_{i, t-1}\right)=\beta_{0}+\beta_{3}\left(\bar{X}_{i 3, t+1}-\bar{X}_{i 3, t-1}\right)+\beta_{4}\left(\bar{X}_{i 4, t+1}-\bar{X}_{i 4, t-1}\right)+e_{i t} \ldots 4.2
$$

$$
\begin{aligned}
\bar{Y}_{i, t-1} & =\frac{1}{t_{1}} \sum_{t=1}^{t_{1}} Y_{i t}=\text { mean ROA for bank i during the "before interest capping" period } \\
\bar{Y}_{i, t+1} & =\frac{1}{t_{2}} \sum_{\substack{t=1 \\
t_{1}}}^{t_{i t}}=\text { mean ROA for bank i during the "after interest capping" period } \\
\bar{X}_{\mathrm{i}, t-1} & =\frac{1}{\mathrm{t}_{1}} \sum_{\mathrm{t}=1}^{\mathrm{X}_{\mathrm{i}}} \mathrm{X}_{\mathrm{t}}=\text { mean CCH for bank i during the "before interest capping" period }
\end{aligned}
$$




$$
\begin{aligned}
& \overline{\mathrm{X}}_{\mathrm{i} 3, \mathrm{t}+1}=\frac{1}{\mathrm{t}_{2}} \sum_{\mathrm{t}=1}^{\mathrm{t}_{2}} \mathrm{X}_{\mathrm{i} 3 \mathrm{t}}=\text { mean CCH for bank i during the "after interest capping" period } \\
& \overline{\mathrm{X}}_{\mathrm{i} 4, \mathrm{t}-1}=\frac{1}{\mathrm{t}_{1}} \sum_{\mathrm{t}=1}^{\mathrm{t}_{2}} \mathrm{X}_{\mathrm{i} 4 \mathrm{t}}=\text { mean CI for bank i during the "before interest capping" period } \\
& \overline{\mathrm{X}}_{\mathrm{i} 4, \mathrm{t}+1}=\frac{1}{\mathrm{t}_{2}} \sum_{\mathrm{t}=1}^{\mathrm{t}_{1}} \mathrm{X}_{\mathrm{i} 4 \mathrm{t}}=\text { mean CI for bank i during the "after interest capping" period }
\end{aligned}
$$

\section{RESULTS AND DISCUSSIONS}

\subsection{Descriptive Statistics}

This section contains the descriptive statistics of all the variables included in the analysis. According to Kothari (2014), descriptive statistics provide important statistical measures that are used to summarize research data. Table 4.1 presents the summary statistics for Credit history of customer, Customer income and Return on Assets for the

\begin{tabular}{|c|c|c|c|c|c|c|}
\hline & 2013 & 2014 & 2015 & 2016 & 2017 & 2018 \\
\hline \multicolumn{7}{|c|}{ Collateral Requirements (Credit history of customer (in Kshs.000,000)) } \\
\hline Mean & 1,012 & 872 & 602 & 19,200 & 20,790 & 20,000 \\
\hline Std. Dev. & 1,102 & 2,204 & 3,302 & 20,111 & 20,640 & 31,211 \\
\hline Minimum & 1,120 & 1,420 & 1,221 & 2,103 & 6,103 & 7,621 \\
\hline Maximum & 18,135 & 10,320 & 8,215 & 2,012 & 11,021 & 15,150 \\
\hline \multicolumn{7}{|c|}{ Customer income (in Ksh.000,000) } \\
\hline Mean & 1,360 & 830 & 722 & 1,032 & 2,340 & 5,103 \\
\hline Std. Dev. & 204 & 820 & 2,340 & 9,100 & 10,300 & 11,320 \\
\hline Minmum & 1,345 & 2,012 & 2,630 & 6,701 & 5,021 & 6,320 \\
\hline Maximum & 3,103 & 6,120 & 3,781 & 9,134 & 8,010 & 93,210 \\
\hline \multicolumn{7}{|c|}{ Return on Assets $(\%)$} \\
\hline Mean & 9.09 & 9.10 & 8.10 & 8.22 & 5.88 & 5.17 \\
\hline Std. Dev. & 12.30 & 11.20 & 21.12 & 21.10 & 22.22 & 13.20 \\
\hline Minimum & 2.10 & 6.11 & 6.10 & 7.10 & 2.15 & 2.32 \\
\hline Maximum & 12.12 & 13.10 & 11.10 & 16.10 & 12.20 & 10.22 \\
\hline
\end{tabular}
years 2013 to 2018 .

Table 4.1: Descriptive Statistics (2013 to 2018)

\section{Source: Research 2020}

\subsection{Interpretation of the Results}

Table 4.1 above shows the secondary data on Document Analysis Guide spread from the mean, standard deviation, minimum and maximum of the descriptive statistics of secondary data. Credit history of customer had the highest mean of Ksh.20790 in 2017 and a standard deviation of Ks.31211 in 2018. The customer income had a mean of ksh.5103 and a standard deviation of Ksh.11320 in 2018 to 2016.

The highest mean for ROA was $9.10 \%$ in 2014 with a standard deviation of $22.22 \%$ in 2017 . The results show that before the interest rate capping, all the variables had lower values for period 2013 to 2015 but then it increased in the period 2016 to 2018 when there was interest rate capping. This implies that interest capping has either positive or negative impact on the financial performance of commercial banks.

\subsection{Panel Specification Test}

To determine the suitability of the panel data for statistical analysis, various tests which include, panel unit root test, granger-casuality test, multicollinearity test, panel-level heteroscedasticity test, serial correlation test and the Hausman effect test were conducted. In addition, panel cointegration test was conducted to determine if the variables used in the study had along run association.

\subsubsection{Unit root test}

To establish whether the data employed in this study is stationary or not, the study employed the Fisher- type Augmented Dickey and Fuller (ADF) and Fisher- type Phillips and Perro (PP) (Choi, 2001) for the purpose of a wider comparison, thus, the decision rule here is that if the p value is less than $0.05 \mathrm{H} 0$ is rejected and the acceptance of $\mathrm{H} 1$ and vice versa. 
Table 4.2: Stationarity test results

\begin{tabular}{|l|l|l|l|l|}
\hline Variable & Test & Statistic & P', & Decision \\
\hline \multirow{2}{*}{ CHC } & Augmented-Dickey Fuller & -14.43681 & .0000 & Stationary \\
\cline { 2 - 5 } & Phillips-Perron & -14.17069 & .0000 & Stationary \\
\hline \multirow{3}{*}{ CI } & Augmented-Dickey Fuller & -6.99586 & .0000 & Stationary \\
\cline { 2 - 5 } & Phillips-Perron & -21.52153 & .0000 & Stationary \\
\cline { 2 - 5 } & Augmented-Dickey Fuller & -20.24955 & .0000 & Stationary \\
\cline { 2 - 5 } & Phillips-Perron & -20.25324 & .0000 & Stationary \\
\cline { 2 - 5 } & Phillips-Perron & 188.793 & .0000 & Stationary \\
\hline
\end{tabular}

\section{Source: Research 2020}

The output on Table 4.2 was based on the ADF and PP panel unit root test results carried out on each of the variables and the entire group. As may be seen from the earlier formulated hypothesis, the two methods test the same null hypothesis of non-stationarity. The result indicated that the null hypothesis of "non-stationarity" was rejected for all the variables since the associated $p$-values were less than the 5\% statistical level of significance and was consistent with the two methods applied for comparison. It can, therefore, be deduced that all the variables used in the study were stationary thereby informing the acceptance of the alternative hypothesis.

\subsubsection{Serial correlation test}

The Arellano-Bond Serial Correlation test results for the panel data are showm in table 4.3

Table 4.3: Arellano-Bond Serial Correlation Test

Arellano-Bond Serial Correlation Test

Equation: Untitled

Date: 09/25/20 Time: 17:50

Sample: 20132018

Included observations: 57

\begin{tabular}{ccccr}
\hline \hline Test order & m-Statistic & rho & SE(rho) & Prob. \\
\hline \hline AR(1) & -1.462474 & -0.757519 & 0.517971 & 0.1436 \\
AR(2) & -1.420482 & -0.525278 & 0.369789 & 0.1555 \\
\hline \hline
\end{tabular}

\section{H0: No first-order autocorrelation tests carried out at 5\% significance level}

The results show that the m-statistic was not statistically significant at 5\% level of significance. This implied that the null hypothesis was not rejected for the model hence there doesn't exist first-order autocorrelation nor second-order autocorrelation in the panel data employed in the analysis.

\subsubsection{Multicollinearity test}

In the study the variance inflation factor (VIF) was used as an indicator of multicollinearity. As a rule of thumb, lower levels of variance inflation factor (VIF) are desirable as higher levels of VIF are known to affect adversely the results associated with multiple regression analysis. Garson (2012) asserts that the rule of thumb is that if VIF > 4.0 multicollinearity is a problem. The results of the analysis are shown in table 4.4 below

Table 4.4: Test for Multicollinearity

\begin{tabular}{|l|l|l|}
\hline Variable & VIF & $1 / \mathrm{VIF}$ \\
\hline CHC & 1.92 & 0.521994 \\
\hline CI & 1.14 & 0.880207 \\
\hline
\end{tabular}

Source: Research 2020

As can be observed in table 4.4, CHC had a VIF value of 1.92 and CI had a VIF value of 1.14. The results were established to be less than 10 and thus according to Field (2009), there is no Multicollinearity. This is further supported by the values of the correlation matrix in table 4.5

Table 4.5: Correlation Matrix for the independent variables

\begin{tabular}{|c|c|c|c|}
\hline 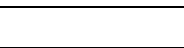 & ROA & $\mathrm{CHC}$ & CI \\
\hline ROA & 1.000 & & \\
\hline $\mathrm{CHC}$ & -.551 & 1.000 & \\
\hline CI & .092 & -.373 & 1.000 \\
\hline
\end{tabular}

Source: Research 2020

The correlation between the independent variables are all less than 0.7 hence indicating the absence of multicolinearity (Tabachnick\&Fidell 2007). The established correlations between the ROA and loan underwriting indicators $(\mathrm{CHC}$ and $\mathrm{CI})$ were negative moderate correlation since they were all above 0.3 and less than 0.5 . For 
the loan underwriting indicators $(\mathrm{CHC}$ and $\mathrm{CI})$, the study established a negative strong correlation between ROA and $\mathrm{CHC}(-0.551)$ and a very weak correlation between ROA and CI (Chang et al., 2010).

\subsubsection{Hausman effect test}

To establish which estimation effects (between fixed and random) provided superior results for the study, Hausman test was carried out for the specified panel regression model. The test was conducted against the null hypothesis that random effect model was the preferred model. If the chi-square statistic was significant at $5 \%$ significance level, the null hypothesis is rejected; otherwise, the null hypothesis is accepted.

Table 4.6: Hausman test result

Correlated Random Effects - Hausman Test

Equation: Untitled

Test cross-section random effects

\begin{tabular}{lccr}
\hline \hline Test Summary & Chi-Sq. Statistic & Chi-Sq. d.f. & Prob. \\
\hline \hline Cross-section random & 3.773616 & 6 & 0.4375 \\
\hline \hline
\end{tabular}

Table 4.6 display the Hausman specification test results for panel regression equation. The test results show that the chi-square statistics for the panel equation was not statistically significant at $5 \%$ level as indicated by the p-values of 0.4375 . The study, therefore, rejects the null hypothesis that the random effects estimation was appropriate for the model at 5\% significance level. Nevertheless, the fixed effect (FEM) and random effect (REM) estimators are also biased and inconsistent unless the number of time periods is large $n \geq 30$ (Baltagi, 2002). The study therefore chose to employ the panel equations for dynamic GMM.

\subsection{Inferential Statistics}

\subsubsection{Effect of Collateral requirements on financial performance of commercial banks in Kenya}

The first objective was to establish the relationship between collateral requirements and financial performance of commercial banks in Kenya. The formulated null hypothesis was that collateral requirement has no significant effect on the financial performance of commercial banks. The results of the analysis are presented in Table 4.7

Table 4.7: Two-step dynamic GMM estimated results of the effect of Collateral requirements on Firm Value Dependent Variable: ROA

Method: Panel Generalized Method of Moments

Transformation: First Differences

Date: 09/03/20 Time: 2:23

Sample (adjusted): 2013- 2018

Periods included: 6

Cross-sections included: 43

Total panel (balanced) observations: 258

White period instrument weighting matrix

White period standard errors \& covariance (d.f. corrected)

Instrument specification: @DYN(ROA,-2) ROACHCCI

Constant added to instrument list

\begin{tabular}{lrrrr}
\hline \hline Variable & Coefficient & Std. Error & t-Statistic & Prob. \\
\hline \hline ROA(-1) & 0.00154 & 0.000480 & 3.2266 & 0.0000 \\
CHC & -0.31481 & 0.049661 & -6.3390 & 0.0000 \\
CI & 0.04244 & 0.041213 & 1.02986 & 0.0741 \\
\hline \hline & Effects Specification & \\
Cross-section fixed (first differences) & & & 1.896549 \\
\hline \hline Mean dependent var & -0.122250 & S.D. dependent var & 1290.682 \\
S.E. of regression & 2.017809 & Sum squared resid & 39 \\
J-statistic & 38.12567 & Instrument rank & \\
Prob(J-statistic) & 0.372955 & & \\
\hline \hline
\end{tabular}


The coefficient of lagged ROA for model 2 is 0.00154 . Thus the lower bound of lagged return on Assets in the GMM specification should be 0.00154 . On the relationship between credit history of customer and ROA, the study established a negative relationship significant at 5\% level of significance. On the relationship between customer income and ROA, the study established a positive relationship which was however not significant at $5 \%$ level of significance. The regression equation for the relationship therefore takes the form

$$
R O A_{i t}=0.00154 R O A_{i t-1}-0.31481 D C C_{i t}+0.04244 L T_{i t}
$$

Hypothesis one $\left(\mathrm{H}_{1 \mathrm{a}}\right)$ states that bank Credit history of customer has no significant relationship with ROA of commercial banks. The t-test results $(\mathrm{t}=-6.3390 ; \mathbf{p}=\mathbf{0 . 0 0 0})$ indicate that the relationship between $\mathrm{CHC}$ and ROA is tatistically significant. This finding rejected the stated null hypothesis with $95 \%$ confidence and concluded that credit history of customer has a significant effect on the financial performance of commercial banks.

Hypothesis one $\left(\mathrm{HO}_{1 \mathrm{~b}}\right)$ stated that customer income has no significant relationship with ROA of commercial banks. The t-test results $(t=1.02986 ; \mathbf{p}=\mathbf{0} .0741)$ indicate that the relationship between customer income and ROA is not statistically significant. This finding failed to reject the stated null hypothesis with $95 \%$ confidence and concludes that customer income has a non-significant effect on the financial performance of commercial banks.

The Hansen $\mathbf{J}$ statistic for the model is 38.12567 with a corresponding p-value of 0.372955 which is greater than 0.1 . Therefore, the null hypothesis of the validity of the instruments was not rejected at one per cent level of significance. Therefore, the instruments employed by the model were appropriate.

Further to the secondary data analysis, primary data was collected on how poor collateral requirements affect financial performance of commercial banks in Kenya. One hundred and twenty nine (129) questionnaires were issued to all the 43 commercial banks registered in Kenya targeting 43 Bank managers, 43 credit officers and 43 operations managers. One hundred and twelve (112) questionnaires were returned representing 86.82\% response rate. The response rate was considered adequate given the recommendation by Kothari (2004) who suggested that $60 \%$ to $70 \%$ response rate is adequate. Table 4.8 displays the views of the respondents on the statements.

Table 4.8: Collatera requirements and Financial Performance of commercial banks in Kenya

\begin{tabular}{|c|c|c|c|c|c|c|c|}
\hline Statement & $\begin{array}{l}\text { Not } \\
\text { At all \% }\end{array}$ & $\begin{array}{l}\text { To a } \\
\text { Less } \\
\text { extent \% }\end{array}$ & $\begin{array}{l}\text { To a } \\
\text { Moderate } \\
\text { extent \% }\end{array}$ & $\begin{array}{l}\text { To a } \\
\text { Great } \\
\text { extent } \%\end{array}$ & $\begin{array}{l}\text { To a } \\
\text { Greater } \\
\text { extent } \%\end{array}$ & Mean & Std. Dev. \\
\hline $\begin{array}{l}\text { Weak loan under- } \\
\text { Writing processes }\end{array}$ & 2.7 & 6.8 & 21.9 & 42.5 & 26.0 & 3.82 & 0.991 \\
\hline $\begin{array}{l}\text { Influence loan } \\
\text { Repayment ability }\end{array}$ & & & & & & & \\
\hline $\begin{array}{l}\text { The quality of credit officers } \\
\text { Determine the nature of } \\
\text { Appraisal and extent of NPLs }\end{array}$ & 2.7 & 4.1 & 21.6 & 35.1 & 36.5 & 3.99 & 1.000 \\
\hline $\begin{array}{l}\text { The term of the loan given } \\
\text { Influence loan repayment }\end{array}$ & 4.1 & 1.4 & 33.8 & 47.3 & 13.5 & 3.65 & 0.883 \\
\hline $\begin{array}{l}\text { Poor loan lending policies } \\
\text { Lead to debt collection costs }\end{array}$ & 0.00 & 9.5 & 35.1 & 32.4 & 23.0 & 3.69 & 0.935 \\
\hline $\begin{array}{l}\text { Loan underwriting processes } \\
\text { Assist in reducing NPLs }\end{array}$ & 1.4 & 13.5 & 39.2 & 27.0 & 18.9 & 3.49 & 0.996 \\
\hline $\begin{array}{l}\text { Loan underwriting in terms of } \\
\mathrm{CCH}, \mathrm{CI} \text { affects ROA }\end{array}$ & 0.00 & 12.2 & 24.3 & 32.4 & 31.1 & 3.82 & 1.012 \\
\hline $\begin{array}{l}\text { Loan underwriting processes } \\
\text { Assisted in minimizing DCC } \\
\text { In banks }\end{array}$ & 2.7 & 4.1 & 21.9 & 52.1 & 19.2 & 3.81 & 0.892 \\
\hline $\begin{array}{l}\text { Loan underwriting process has } \\
\text { Increased profits in banks } \\
\text { Average Mean }\end{array}$ & 2.7 & 8.1 & 29.7 & 39.2 & 20.3 & $\begin{array}{c}3.66 \\
\mathbf{3 . 7 4 2 3}\end{array}$ & $\begin{array}{r}0.983 \\
\mathbf{0 . 9 6 1 5}\end{array}$ \\
\hline
\end{tabular}

Source: Researcher 2020

Data on table 4.8 show responses on statements regarding the effect of collateral requirements on financial performance of commercial banks in Kenya. All the responses in all the statements indicated that collateral requirements in terms of $\mathrm{CHC}$ and $\mathrm{CI}$ afftects the financial performance of commercial banks negatively as it affects the bank's liquidity position. The mean score of response regarding collateral requirements was 3.7423 on a 5 point scale and the overall average standard deviation was 0.9615 . This study is consistent with a study carried out by (Nduati 2013) on the effect of interest rate spread on financial performance of commercial banks in Kenya and found that interest rate spread affect performance of assets in commercial banks as it increases the cost of loans charged on borrowers, regulations have far reaching effects on assets of non-performing loans. 
4.4.2 Effect of interest rate regulation on the relationship between loan underwriting procedures and financial performance of commercial banks in Kenya.

The second objective sought to determine the effect of interest rate regulation on the relationship between loan underwriting procedures and financial performance of commercial banks in Kenya. The study data were divided into two periods: the period before the interest rate capping (2013-2015) and the period after the interest rate capping (2016-2018). The independent samples T-test was used to establish if there was a significant difference in the means of the study variables and pooled regression with differencing was used to estalish whether changes in ROA between the two periods was a result of the changes in the explanatory variables between the two periods.

4.4.1b Group Statistics for ROA and Loan Underwriting Procedures before and after interest rate capping Table 4.9: Group Statistics for ROA and Loan Portfolio management practices before and after interest rate capping

\begin{tabular}{|l|l|l|l|l|l|}
\hline VARIABLE & GROUP & $\mathrm{N}$ & MEAN & SD & SE.MEAN \\
\hline \multirow{2}{*}{ ROA } & BEFORE CAP (\%) & 129 & 8.8974401 & 1.995 & .425 \\
\cline { 2 - 6 } & AFTER CAP (\%) & 86 & 5.2565423 & 3.102 & .661 \\
\hline CI & $\begin{array}{l}\text { BEFORE CAP } \\
\text { (KSHS'.000,000) }\end{array}$ & 129 & 82.87 & 32.273 & 6.633 \\
\cline { 2 - 6 } & $\begin{array}{l}\text { AFTER CAP } \\
\text { KSHS'000,000) }\end{array}$ & 86 & 20.43 & 38.165 & 8.857 \\
\hline & $\begin{array}{l}\text { BEFORE CAP } \\
\text { (KSHS'000,000) }\end{array}$ & 129 & 2368.67 & 9.118 & 8.975 \\
\cline { 2 - 6 } & $\begin{array}{l}\text { AFTER CAP } \\
(\text { KSHS'000,000) }\end{array}$ & 86 & 1388.81 & 7.347 & 1.853 \\
\hline
\end{tabular}

\section{Source: Research 2020}

The results presented in Table 4.9 depicts that the mean ROA before the interest rate capping of 8.8974401 and standard deviation of 1.995 was higher than the mean ROA after the interest rate capping in 2016 (Mean=5.2565423, $\mathrm{SD}=3.102$ ). The results depicts that the introduction of interest rate capping resulted to a decline in the ROA of the commercial banks in Kenya. With regard to CHC, the study etablished a mean of Kshs 2529.3 million before the introduction of interest rate capping and a mean of Kshs 1089.5 million after the interest rate capping with values deviating from these means by 15.256 and 11.546 respectively.

For customer income, means of Kshs2368.67 million ( $\mathrm{SD}=9$.118) and Kshs1388.81 million (SD=7 .347) were obtained for the before and after interest rate capping periods which indicates that the introduction of interest rate regulation consequently led to the reduction in scrutinizing credit history of customer for the commercial banks in Kenya.

For the collateral requirements indicators, the study established a mean of Kshs 82.87 million with a standard deviation of 32.273 before interest rate capping and a mean of Kshs 20.43 million with a standard deviation of 38.165 after interest rate capping for $\mathrm{CHC}$. This indicated a decline of about $75 \%$ in the credit history of customer hence an implication that the introduction of interest rate capping made it easier for loan lendees to service their loans. For customer income, the customer income remained the same indicating that there were no changes in the customer income with the introduction of interest rate regulation.

The results for the independent samples t-test for ROA are as shown in table 4.10 below:

Table 4.10: Independent Samples T-test for the Difference in the Means of ROA

\begin{tabular}{|c|l|l|l|l|l|l|l|l|}
\hline \multicolumn{2}{|c|}{} & \multicolumn{2}{|c|}{$\begin{array}{c}\text { Levene's Test for } \\
\text { Equality of } \\
\text { Variances }\end{array}$} & \multicolumn{5}{|c|}{ t-test for Equality of Means } \\
\cline { 2 - 8 } & F & Sig. & T & Df & $\begin{array}{l}\text { Sig. (2- } \\
\text { tailed) }\end{array}$ & $\begin{array}{l}\text { Mean } \\
\text { Diff. }\end{array}$ & $\begin{array}{l}\text { SE } \\
\text { Diff. }\end{array}$ \\
\hline ROA & $\begin{array}{l}\text { Equal } \\
\text { variances } \\
\text { assumed }\end{array}$ & 3.193 & .031 & 3.815 & 41 & .020 & 3.64089 & .78629 \\
\cline { 2 - 9 } & $\begin{array}{l}\text { Equal } \\
\text { variances not } \\
\text { assumed }\end{array}$ & & 3.815 & 36.836 & .020 & 3.64089 & .78629 \\
\hline
\end{tabular}

\section{Source; Reserch 2020}

The t-test results for the difference in the means of ROA between the two periods shown in table 4.10 shows that a $t$-test value of 3.815 together with $p$-value of 0.020 were obtained. This indicates that the difference in the mean ROA before and after the interest rate capping was statististically significant. The results imply that the introduction of interest rate regulation led to a significant change in the profitability of the banks with the period 
after the capping registering smaller profitability values than the period before the capping. This also points to the fact that banks relied majorly on the higher interest rates charged for their profitability margins hence the need for diversification of the focus to other profitability drivers.

\subsubsection{Effect of Interest rate regulation on the relationship between management of collateral requirements} and financial performance of commercial banks in Kenya

To establish the effect of interest rate regulation on the relationship between collateral requirements and financial performance of commercial banks, the study first applied the independent samples t-test to establish whether there was a significant difference in the means of CHC and CI for the two periods (before interest rate capping (20132015 ) and that after the interest rate capping (2016-2018)) and then applied pooled OLS regression analysis of the difference in the ROA between the period before interest rate capping (2013-2015) and that after the interest rate capping (2016-2018) on the difference in CHC and CI between those two periods i.e.

The results for the independent samples t-test for $\mathrm{CHC}$ and $\mathrm{CI}$ are as shown in table 4.11 below:

Table 4.11: Independent Samples T-test for the Difference in the Means of Collateral requirements measures

\begin{tabular}{|c|c|c|c|c|c|c|c|c|}
\hline \multicolumn{9}{|c|}{ Independent Samples Test } \\
\hline & & \multicolumn{2}{|c|}{$\begin{array}{l}\text { Levene's Test for } \\
\text { Equality of Variances }\end{array}$} & \multicolumn{5}{|c|}{ t-test for Equality of Means } \\
\hline & & $\mathrm{F}$ & Sig. & $\mathrm{T}$ & Df & $\begin{array}{l}\text { Sig. (2- } \\
\text { tailed) }\end{array}$ & $\begin{array}{l}\text { Mean } \\
\text { Diff. }\end{array}$ & $\begin{array}{l}\text { SE } \\
\text { Diff. }\end{array}$ \\
\hline \multirow[t]{2}{*}{$\mathrm{CHC}$} & $\begin{array}{l}\text { Equal } \\
\text { variances } \\
\text { assumed }\end{array}$ & 3.099 & .003 & 4.500 & 84 & .000 & 62.47 & .28703 \\
\hline & $\begin{array}{l}\text { Equal } \\
\text { variances not } \\
\text { assumed }\end{array}$ & & & 4.500 & 77.836 & .000 & 62.47 & $\dot{2} 8703$ \\
\hline \multirow[t]{2}{*}{$\mathrm{CI}$} & $\begin{array}{l}\text { Equal } \\
\text { variances } \\
\text { assumed }\end{array}$ & .107 & .743 & .317 & 84 & .751 & .07055 & .22269 \\
\hline & $\begin{array}{l}\text { Equal } \\
\text { variances not } \\
\text { assumed }\end{array}$ & & & .317 & 77.836 & .751 & .07055 & .22269 \\
\hline
\end{tabular}

\section{Source: Research 2020}

The test for the difference in means of $\mathrm{CHC}$ and $\mathrm{CI}$ before and after interest capping indicate that the difference in the means of $\mathrm{CHC}$ between the two periods was statistically significant $\quad(t=4.500, \mathrm{p}=.000)$ at $5 \%$ level of significance. However, the difference in the mean of CI between the two periods was not statistically significant $(\mathrm{t}=.317, \mathrm{p}=.751)$ at $5 \%$ level of significance. This indicates that the introduction of interest capping caused sigficant changes in the credit history of customer for the commercial banks but caused no significant difference in customer income.

The effect of interest rate regulation on the relationship between loan underwriting and ROA was established by Entity de-meaned OLS Fixed Effects estimation approach combined with changes specifications in which the difference in the mean ROA between the period before interest rate capping (2013-2015) and that after the interest rate capping (2016-2018) is regressed on the difference in CHC and CI between those two periods i.e.

Where

$$
\left(\bar{Y}_{i, t+1}-\bar{Y}_{i, t-1}\right)=\beta 0+\beta_{3}\left(\bar{X}_{i 3, t+1}-\bar{X}_{i 3, t-1}\right)+\beta_{4}\left(\bar{X}_{i 4, t+1}-\bar{X}_{i 4, t-1}\right)+e_{i t} \ldots 3.1
$$

$$
\begin{aligned}
& \bar{Y}_{i, t-1}=\frac{1}{t_{1}} \sum_{t=1}^{t_{1}} Y_{i t}=\text { mean ROA for bank i during the "before interest capping" period } \\
& \bar{Y}_{i, t+1}=\frac{1}{t_{2}} \sum_{\substack{t=1 \\
t_{2}}}^{t_{1}} Y_{i t}=\text { mean ROA for bank i during the "after interest capping" period } \\
& \bar{X}_{i 3, t-1}=\frac{1}{t_{1}} \sum_{t=1}^{t_{2}} X_{i 3 t}=\text { mean CCH for bank i during the "before interest capping" period } \\
& \bar{X}_{i 3, t+1}=\frac{1}{t_{2}} \sum_{t=1} X_{i 3 t}=\text { mean CCH for bank i during the "after interest capping" period }
\end{aligned}
$$




$$
\begin{gathered}
\overline{\mathrm{X}}_{\mathrm{i} 4, \mathrm{t}-1}=\frac{1}{\mathrm{t}_{1}} \sum_{\mathrm{t}=1}^{\mathrm{t}_{1}} \mathrm{X}_{\mathrm{i} 4 \mathrm{t}}=\text { mean CI for bank i during the "before interest capping" period } \\
\overline{\mathrm{X}}_{\mathrm{i} 4, \mathrm{t}+1}=\frac{1}{\mathrm{t}_{2}} \sum_{\mathrm{t}=1}^{\mathrm{x}_{2}} \mathrm{X}_{\mathrm{i} 4 \mathrm{t}}=\text { mean CI for bank i during the "after interest capping" period }
\end{gathered}
$$

The regression analysis results are shown in table 4.12.

Table 4.12: Regression model results for Collateral Requirements and ROA

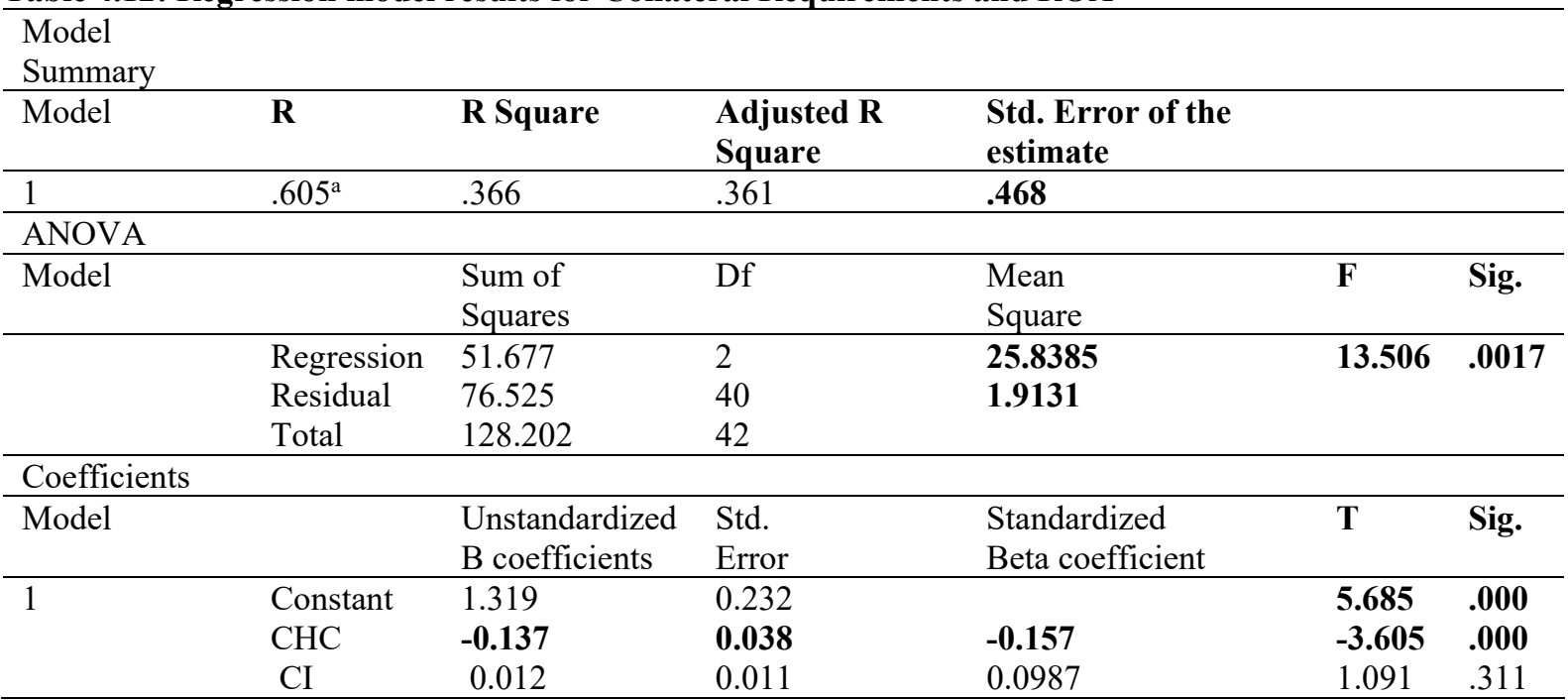

\section{a. Predictors: (Constant), $\mathrm{CHC}, \mathrm{CI}$}

b. Dependent Variable: ROA

The model summary results in Table 4.12 present the fitness of model used. The coefficient of determination $\left(\mathrm{R}^{2}\right)$ value of 0.366 was obtained meanning that changes in loan underwriting indicators $(\mathrm{CHC}$ and $\mathrm{CI})$ between the two periods could explain $36.6 \%$ of the variations in the changes in ROA of commercial banks. The results on the analysis of the variance (ANOVA) indicate that the overall model was statistically significant $(\mathrm{F}=\mathbf{1 3 . 5 0 6}$, $\mathbf{p}=. \mathbf{0 0 1 7}$ ) at $5 \%$ level of significance. The results imply that the change in the collateral requirements was a good predictor of the changes in the ROA of commercial banks. Regression coefficient results showed that $\mathrm{CHC}$ had a negative relationship with ROA as indicated by the coefficient -0.137 implying that the decline in the credit history of customer resulted in an increase in the ROA of the banks. On the other hand change in CI between the two periods had a positive relationship with ROA implying that if the change was positive, the change in ROA would also be positive. Based on the unstandardized beta coefficients the regression model becomes

$$
\left(\bar{Y}_{i, t+1}-\bar{Y}_{i, t-1}\right)=1.319-0.137\left(\bar{X}_{i 3, t+1}-\bar{X}_{i 3, t-1}\right)+0.012\left(\bar{X}_{i 4, t+1}-\bar{X}_{i 4, t-1}\right)
$$

The standardized beta coefficients indicate that $\mathrm{CHC}$ had a greater effect size as shown by its larger standardized beta value of 0.038 indicating that a unit increase in poor credit history of customer results to $3.8 \%$ decline in ROA hence the need for the commercial banks to ensure improved credit history of customer to ensure increased ROA.

The t-test for the significance of the regression coefficients indicated that the relationship between $\mathrm{CHC}$ and ROA was statistically significant at $5 \%$ level of significance $(\mathrm{t}=-3.605, \mathrm{p}=.000)$ while the effect of customer income on ROA was not statistically signicant $(\mathrm{t}=1.091, \mathrm{p}=.311)$

Further, primary data was collected on how interest rate regulations affect loan underwriting procedures and financial performance of commercial banks in Kenya. Table 4.13 displays the views of the respondents on the statements. 
Table 4.13: Effect of Interst rate regulation on the relationship between loan underwriting procedures and Financial Performance of commercial banks in Kenya

\begin{tabular}{|c|c|c|c|c|c|c|c|}
\hline Statement & $\begin{array}{c}\text { Not } \\
\text { At all \% }\end{array}$ & $\begin{array}{c}\text { To a } \\
\text { Less } \\
\text { extent \% }\end{array}$ & $\begin{array}{l}\text { To a } \\
\text { Moderate } \\
\text { extent } \%\end{array}$ & $\begin{array}{l}\text { To a } \\
\text { Great } \\
\text { extent \% }\end{array}$ & $\begin{array}{l}\text { To a } \\
\text { Greater } \\
\text { extent } \%\end{array}$ & Mean & $\begin{array}{l}\text { Std. } \\
\text { Dev. }\end{array}$ \\
\hline Interest rate regulation & 2.7 & 19.2 & 23.3 & 37.0 & 17.8 & 3.48 & 1.082 \\
\hline $\begin{array}{l}\text { Increase or decrease of } \\
\text { Interest rates affects } \\
\text { Performance of banks }\end{array}$ & 0.00 & 16.2 & 23.0 & 36.5 & 24.3 & 3.69 & 1.019 \\
\hline $\begin{array}{l}\text { The capping of interest } \\
\text { Rates In } 2016 \text { increased } \\
\text { Demands for Loans and } \\
\text { Increased bank's profits }\end{array}$ & 8.1 & 18.9 & 33.8 & 27.0 & 12.2 & 3.16 & 1.123 \\
\hline $\begin{array}{l}\text { There is a relationship } \\
\text { Between IRR loan portf. } \\
\text { Affect Performance of banks }\end{array}$ & 0.00 & 21.6 & 27.0 & 29.7 & 21.6 & 3.51 & 1.063 \\
\hline $\begin{array}{l}\text { IRR affect loan portf. Mgt } \\
\text { In commercial banks }\end{array}$ & 2.7 & 6.8 & 35.1 & 44.6 & 0.00 & 3.54 & 0.879 \\
\hline $\begin{array}{l}\text { Competition in comm. bank s } \\
\text { lead to differences in IR } \\
\text { Interest rate changes affect }\end{array}$ & 4.1 & 12.2 & 31.1 & 4.5 & 12.2 & 3.45 & 0.995 \\
\hline Performance of banks & 0.00 & 10.8 & 35.1 & 39.2 & 14.9 & 3.43 & 0.876 \\
\hline IRR afect loan portfolio mgt. & 1.4 & 12.2 & 43.8 & 31.9 & 10.8 & 3.49 & 0.895 \\
\hline $\begin{array}{l}\text { Poor loan inderwriting leads } \\
\text { To NPLs }\end{array}$ & 2.7 & 9.5 & 32.4 & 40.5 & 14.9 & 3.55 & 0.752 \\
\hline Average Mean & & & & & & 3.9125 & 0.9649 \\
\hline
\end{tabular}

\section{Source: Research 2020}

Table 4.13 shows responses on statements regarding the effect of interest rate regulation on the relationship between collareal equirements and financial performance of commercial banks in Kenya. All the responses in all the statements indicated that interest rate regulation and collateral requirements in terms of CHC and CI afftects the financial performance of commercial banks negatively as it affects the bank's liquidity position.

The mean score of response regarding collateral requirements was 3.9125 on a 5 point scale and the overall average standard deviation was 1.9649 . The findings of the current study is in support of a study conducted by (Gravin 2010) on the effect of interest rate spread on the performance of Banking Industry in Kenya and the findings indicated that the Central bank regulation, credit risk and macroeconomic environment played a major role in influencing the extent of interest rate spread and hence contributed to the performance of banking industry (Kisivuliessendi 2013)

\section{DISCUSSION OF RESULTS, FINDINGS AND CONCLUSIONS}

5.2.1 Effect of collateral requirements and financial performance of commercial banks in Kenya.

The first objective of the study sought to establish the relationship between collateral requirements and financial performance of commercial banks in Kenya.

Ho1.1: Credit history of customer has no significant relationship with Return on Assets of commercial banks in Kenya.

Ho1.2: Customer income has no significant relationship with Return on Assets of commercial banks in Kenya. The findings on secondary data on the relationship between credit history of customer and ROA established a negative relationship and significant at 5\% level of significance. On the relationship between customer income and ROA, the study established a positive relationship which was however not significant at $5 \%$ level of significance.

The findings of the study revealed that, the test for the difference in means of CHC and CI before and after interest capping indicated that the difference in the means of $\mathrm{CHC}$ between the two periods was statistically significant $(t=4.500, \mathrm{p}=.000)$ at $5 \%$ level of significance. However, the difference in the mean of CI between the two periods was not statistically significant $(\mathrm{t}=.317, \mathrm{p}=.751)$ at $5 \%$ level of significance. This indicates that the introduction of interest rate capping caused significant changes in the investigation of credit history of customer for the commercial banks but caused no significant difference in customer income.

Hypothesis one $\left(\mathrm{H}_{1 \mathrm{a}}\right)$ stated that credit history of customer have no significant relationship with ROA of commercial banks. The t-test results $(\mathrm{t}=-6.3390 ; \mathbf{p}=\mathbf{0 . 0 0 0})$ indicate that the relationship between $\mathrm{CHC}$ and ROA is statistically significant. This finding rejected the stated null hypothesis with $95 \%$ confidence and 
concluded that credit history of customer has a significant effect on the financial performance of commercial banks. Hypothesis one $\left(\mathrm{H}_{1 \mathrm{~b}}\right)$ stated that customer income has no significant relationship with ROA of commercial banks. The t-test results $(t=1.02986 ; \mathbf{p}=\mathbf{0 . 0 7 4 1})$ indicate that the relationship between customer income and $\mathbf{R O A}$ is not statistically significant. This finding failed to reject the stated null hypothesis with $95 \%$ confidence and concluded that customer income has a non-significant effect on the financial performance of commercial banks. The findings of the study from primary data revealed that loan underwriting procedures had a negative influence on return on assets of commercial banks in Kenya. This is supported by the results of the respondents. The results indicated that collateral requirement affects the financial performance of commercial banks as it affects profitability and liquidity.

5.2.2 Effect of interest rate regulation on the relationship between loan underriting procedures and financial performance of commercial banks in Kenya.

The second objective sought to determine the effect of interest rate regulation on the relationship between loan underwriting procedures and financial performance of commercial banks in Kenya. The study data was divided into two periods: the period before the interest rate capping (2013-2015) and the period after the interest rate capping (2016-2018).

The independent samples T-test was used to establish if there was a significant difference in the means of the study variables and pooled regression with differencing was used to establish whether changes in ROA between the two periods was as a result of the changes in the explanatory variables between the two periods. The results of the study indicated that the mean of ROA before the interest rate capping of 8.8974401 and standard deviation of 1.995 was higher than the mean ROA after the interest rate capping in 2016 (Mean=5.2565423, SD=3.102). The results depicts that the introduction of interest rate capping resulted to a decline in the ROA of the commercial banks in Kenya. For the loan underwriting procedures indicators, the study established a mean Kshs 82.87 million with a standard deviation of 32.273 before interest rate capping and a mean of Kshs 20.43 million with a standard deviation of 38.165 after interest rate capping for $\mathrm{CHC}$. This indicated a decline of about $75 \%$ in the credit history of customer hence an implication that the introduction of interest rate capping made it easier for loan lendees to service their loans. For customer income, the amount of income was the same for the two periods indicating that there ware no changes in the customer income with the introduction of interest rate regulations.

5.2.2.1 Effect of Interest rate regulation on the relationship between collateral requirements and financial performance of commercial banks in Kenya

$H_{04}: 2:$ Interest rate regulation has no significant effect on the relationship between collateral requirements and financial performance of commercial banks in Kenya

To establish the effect of interest rate regulation on the relationship between collateral requirements and financial performance of commercial banks, the study first applied the independent samples t-test to establish whether there was a significant difference in the means of CHC and CI for the two periods (before interest rate capping (20132015) and that after the interest rate capping (2016-2018)) and then applied pooled OLS regression analysis of the difference in the ROA between the period before interest rate capping (2013-2015) and that after the interest rate capping (2016-2018) on the difference in CHC and CI between those two periods. The test for the difference in means of $\mathrm{CHC}$ and $\mathrm{CI}$ before and after interest capping indicate that the difference in the means of $\mathrm{CHC}$ between the two periods was statistically significant $(t=4.500, \mathrm{p}=.000)$ at $5 \%$ level of significance. However, the difference in the mean of CI between the two periods was not statistically significant $(t=.317, p=.751)$ at $5 \%$ level of significance. This indicates that the introduction of interest capping caused significant changes in the credit history of customer for the commercial banks but caused no significant difference in customer income.

\subsection{Conclusion}

The main objective of the study was to determine the effect of interest rate regulation on the relationship between loan underwriting procedures and financial performance of commercial banks in Kenya. Two specific objectives and were derived from the main objective. The first specific objective was to determine the effect of collateral requirements on financial performance of commercial banks in Kenya. The second objective was to determine the effect of interest rate regulation on the relationship between loan underwriting procedures and financial performance of commercial banks in Kenya. Panel data from 2013 to 2018 of 43 commercial banks was analysed using multiple linear regression method. From the discussions of the findings above, it was concluded that collateral requirements, interest rate regulation and loan underwriting procedures have a negative signicant effect on financial performance of commercial banks in Kenya. It can also be concluded that the introduction of interest capping caused significant changes in the credit history of customer and customer income for the commercial banks forcing the banks to diversify their loan portfolios.

The study also concluded that before and after interest rate capping (2013-2015) and (2016-2018), the loan underwriting procedures variables between the two periods was statistically significant implying that it affected the ROA of commercial banks negatively. Based on the above conclusion, the study recommended the following: The management of commercial banks is required to ensure that the terms and conditions of granting loans are 
adhered to before loans are approved. The government should have a fixed interest rate which banks will use as their lending rate because interest rate capping in 2016 brought challenges to the banks until it was repealed in November 2019. Commercial banks should concentrate in lending secured loans with collateral security so that they can be able to recover their money when a customer defaults.

\subsection{Suggestions for Further Research}

The study relied on primary and secondary quantitative data obtained by the use of questionnaires and Document Analysis Guide. This restricted the respondent's opinion and therefore for more conclusive information, the same study should be done using other methods of data collection like interviews. Data analysis was based on the opinion of bank managers, operational managers and credit managers of all the 43 commercial banks in Kenya. For further results, it is suggested that further research be done to seek the opinion of the Governor of Central bank of Kenya and other stakeholders to establish the effect of interest rate regulation on the relationship between loan portfolio management and financial performance of commercial banks in Kenya. The study used census survey design method of sampling whereby all the 43 commercial banks registered in Kenya were the respondents which made it difficult for the researcher to reach all the respondents to get clear understanding of the effect of interest rate regulation on the relationship between loan portfolio management and financial performance of commercial banks in Kenya. It is suggested that further research be undertaken using stratified random sampling techniques where the population will be grouped into strata for easy of data collection. The study captured the only available secondary data for period 2013 to 2018 which are in CBK records and further study is recommended to incude longer periods for the time series data. Further study is also recommended to be carried out of other deposit taking financial institutions such as microfinance banks, mortgage firms and SACCOS since the banking sector faces many challenges including stiff competition from those institutions.

\section{REFERENCES}

Araka H. (2018. Effect of non-performing loans on financial performance of commercial banks in Kenya, JOOUST Masters Thesis, Internationsal Journal of Finance, Accounting and Economics, (IJFAW) ISSN: 2617 - 3135x Vol. 1 (3) 44-51

Bosire et.al (2014). Factors that influence a wide interest rate band in Microfinance Institutions in Kenya, Published MBA Thesis, Ergeton University, Research Journal of finance and accounting, ISSN: 2222-1697 (Paper) ISSN 2222-2847 (online) Vol. 5 No.7 2014

Chpkorir M. \& Osiemo K.E. (2014). An Evaluation of Credit Appraisal Techniques Adopted by commercial banks in Kenya in Lending to small and medium sized Enterprises.

Githinji K.. (2019). Effect of Collateral requirements on financial performance of Agribusiness, small and Micro Enterprise in Nyeri Sub County, Kenya. Masters Thesis (MBA) JKUAT

Gravin J. (2010). Factors affecting banking sector interest rate spread in Kenya. Unpublished Masters Thesis, JKUAT

Kisivuliessendi L. (2013). The Effects of credit risk management on loans portfolio among SACCOS in Kenya. Unpublished MBA Thesis, University of Nairobi.

Kibor A.M. \& Ngahu S.T. (2015). Influence of credit Risk Management on loan performance in commercial banks in Nakuru Town, Kenya.Unpublished Masters Thesis JKUAT. International Journal of Economics, Commerce and management, United Kingdom Vol.III, issue 10, October 2015

Korankye A.A. (2014). Causes and control of loan default or Delinquency in Microfinance Institutions in Ghana. Published MBA Thesis, Central University College Accra,Ghana, Amerian International Journal of Contemprorary Research Vol.4 No.12, December, 2014.

Mokaya A.M. \& Jagongo A. (2014). Corporate loan portfolio diversification and credit risk Management among commercial banks in Kenya. Published MBA Thesis, Kenyatta University (2014), International Journal of current Business and Social Sciences (IJCBSS) Issue 2, Vol. 2 2014. ISSN: 2312-5985.

Munyiri J. (2010). Lending policies and their effects on performance of commercial banks in Kenya. Published Masters Thesis, University of Nairobi.

Mureithi M.W. (2013). The causes of non-performing loans in commercial banks in Kenya.Unplished MBA Thesis, University of Nairobi 2013.

Mwangi S.N. (2014). Effect of lending rates on financial performance of deposit taking Micro Finance Institutions in Kenya.

Nduati P.I. et.al (2013). Effect of interest rate spread on financial performance of commercial Banks in Kenya Published Masters Thesis, University of Nairobi, Kenya

Ngetich J.C. \& Wanjau K. (2011). The effects of interest rate spread on the level of non-performing assets. Acase of commercial banks in Kenya.Unpublished PhD Thesis JKUAT, International Journal of Business and Public Management (ISSN: 2222-6244) Vol.1 (1); Mount Kenya University Journal (2011) April.

Nakayiza K..S. (2013). Interest rates and loan portfolio performance in commercial banks. A case of Centenary 
Bank Entebe Road Branch, Uganda. Unpublished Masters Thesis Lahti Universsity, Uganda 2013

Norhaziah N. \& Mohd N.M. (2012). Factors affecting repayment performance in Microfinance Programs in Malaysia. Unpublished PhD Thesis, University of Utara, Malaysia.

Nyakundi D.O. (2013). Effects of lowering Central Bank rate on the bank's prime rate, an Analysis of Kenyan commercial banks. Published MBA Thesis Kenyatta University. Journal of Finance and Bank Management, Vol. 1 No. 2 December 2013.

Nyaliech C.M. (2017). Factors affecting non-performing loans, a case of KCB Kenya Limited Nairobi Region, Published Masters Thesis Catholic University of East Africa

Paulino M.J. (2018). Credit risk management on financial performance of commercial banks in Juba City, South Sudan. International Journal of Economics and Finance Vol.3, Issue 2 pp 93-116. MBA, Methodist University, Kenya

.Ochieng J.O. (2014). Effect of Central Bank of Kenya prudential guideline and regulations on the financial performance of commercial banks in Kenya. Unpublished MBA, Thesis, University of Nairobi, Kenya (2014).

Ogilo F. et.al (2012). The impact of credit risk management on financial performance of commercial banks in Kenya. Published PhD Thesis, --- DBA Africa Management Review 2012, Vol.3, No.1, 22-37

Ongera J.O. (2016). Influence of loan lending policies on financial performance of commercial banks in Kenya A case of selected banks in Kisii Town; Masters Thesis, International Journal of Economics and commerce and management Vol. IV issue 112016

Otieno (2013). The effect of lending policies on the level of non-performing loans (NPLS) of commercial banks in Kenya, Published Masters Thesis, University of Nairobi.

Pierre B.J. (2017). Impact of Loan Portfolio Management on performance of commercial banks in Rwanda, A case study of Cogebank (2010-2015). Published Masters Thesis, University of Lay Adventist of Kigali Rwanda

Standard Newspaper (2016). Nairobi Kenya, the CBK Governor Patrick Njoroge, the commencement of the new law on reducing interest rates was on September 2016. The Standard Newspaper Daily Publishers PP 9-10

Standard News paper (2016). Nairobi Kenya, The President of the Republic of Kenya Uhuru Kenyatta assented to Bill capping interest rates at 4 percent above the Central Benchmark rate

WafulaM.A. (2013). Factors influencing performance of commercial banks in Kenya. Acase of KCB Bungoma, Unpublished PhD Thesis University of Nairobi, Kenya

Were M. \& J. Wambua (2014). Factors driving interest rate spread of commercial Banks, Empirical Evidence from Kenya. A review of development finance Vol. 4, issue 2 (2014), pp.73-82

Wesean A.K.(2014). The impact of interest rate changes on the profitability of four major commercial banks in Parkistan. International Journal of Accounting and Financial Reporting ISSN 2162-3082, Vol.4 No.1 